IMR

36,1

6

Received 7 March 2017

Revised 9 November 2017

6 April 2018

27 June 2018

24 September 2018

Accepted 3 October 2018

\section{Local horizontal network membership for accelerated global market reach}

\author{
Paul Ryan \\ Trinity College, University of Dublin, Dublin, Ireland \\ Natasha Evers \\ National University of Ireland, Galway, Ireland \\ Adele Smith \\ Maynooth University, Maynooth, Ireland, and \\ Svante Andersson \\ Halmstad University, Halmstad, Sweden
}

\begin{abstract}
Purpose - The purpose of this paper is to explain how some born global firms can leverage the rich social capital in their local (home country) horizontal network for accelerated international market entry and growth. Horizontal networks warrant separate attention from their vertical counterparts, which, along with those focussed on external international contexts, dominate most network studies in the realm of born global research.

Design/methodology/approach - The study utilises a multi-level qualitative approach in the study of a multi-firm population of animators in Ireland that, due to the small domestic market for their product, needed to pursue global customers from inception. The case study domain was purposely selected as a critical exemplar of a local horizontal network operating in a highly globalised industry. The authors collected data through in-depth interviews with 16 company founders. This primary interview data were complemented by interviews with staff at the apposite industry association and triangulated with secondary data on the local and global industry conditions, members' international successes and awards.

Findings - The results demonstrate how active membership of a local horizontal network can be leveraged for the acquisition of international market knowledge and customers for born global ventures. This arises from the sharing of collective market knowledge and communal global customer information within the network to mutual benefit.

Originality/value - Although limited by the specific conditions in this highly globalised, non-competitive industry context, this study is unique in that it finds that cooperative interpersonal and inter-firm relationships embedded in a local horizontal social network, and mediated in part by an institutional support actor, emerge as important levers for a born global's accelerated acquisition of foreign market knowledge and of global customers.

Keywords International marketing, Social capital, Intermediaries, Horizontal networks, Local networks Paper type Research paper

\section{Introduction}

Relevant and timely foreign market knowledge is a critical resource for a firm's international sales growth (Zahra et al., 2000) and particularly necessary for the early international market entry of rapidly internationalising firms (Ruokonen et al., 2008). As is now well-established in the international business and marketing literatures, the born global firm is a unique type of organisational form that, from inception, has a strong intent to rapidly enter and serve multiple international markets (Knight and Cavusgil, 1996; Crick, 2009; Cavusgil and Knight, 2015; Coviello, 2015). The born global founder's deployment of a constellation of personal contacts in international networks has long since been found to facilitate the acquisition of knowledge on foreign market opportunities and customers (Coviello and Munro, 1997; Ellis, 2000; Ellis and Pecotich, 2001; Sharma and Blomstermo, 2003; Crick and Spence, 2005; Loane and Bell, 2006).
\end{abstract}

International Marketing Review Vol. 36 No. 1,2019 pp. $6-30$

(C) Emerald Publishing Limited 0265-1335

DOI 10.1108/IMR-03-2017-0061 
This valuable social capital derives from international personal and business contacts commonly acquired from prior work experiences and business relationships (Crick and Jones, 2000; Prashantham and Dhanaraj, 2010; Ellis, 2000; Jones et al., 2011). Extensive research has demonstrated the founders' useful deployment of relational social capital embedded in their international relationships with vertical exchange partners, principally customers, for accelerated access to foreign market knowledge and extended global market reach (Sasi and Arenius, 2008; Jones et al., 2011; Yli-Renko et al., 2001; Evers and O'Gorman, 2011; Slotte-Kock and Coviello, 2010; Sepulveda and Gabrielsson, 2013). Yet the born global literature is less than replete on the utility of the founders' horizontal network relationships that encompass social exchanges with, and mutual support from friends, family, business associates, even fellow industry players in the form of coopetition, for international market development (Jack et al., 2010; Theodorakopoulos and Figueira, 2012; Crick, 2018).

These horizontal relationships, unlike the vertical associations, commonly occur and are framed in a local context. Recently, an emerging stream of research has found that local business and personal ties of the born global entrepreneur can also be important sources of foreign market intelligence and facilitators of foreign connections and international network entry (Ibeh and Kasem, 2011; Boehe, 2013; Andersson et al., 2013; Prashantham and Birkinshaw, 2015). However, of the evidence to date, findings have diverged. Some research relates that local linkages that share international market intelligence can have a positive impact on the international market development of born globals (Etemad, 2004; Andersson et al., 2013; Boehe, 2013). Contrastingly, other researchers have noted that local relationships may actually hinder international growth (Milanov and Fernhaber, 2014) or at least give rise to concerns in varying contexts (Prashantham and Birkinshaw, 2015).

In an endeavour to shed light on the positive impacts of international market intelligence sharing in a local context, we set out in this study to examine the influence of active membership of a highly collaborative local horizontal network on the rapid multiple international market entry and growth for a set of born global ventures. This study investigates how a purposely selected case study of a collective of born global firms in a local horizontal network leveraged rich internal social capital for accelerated international market entry and growth. This study focusses on a set of Irish indigenous born globals operating in the highly globalised animation industry and exhibiting a benign form of coopetition.

Therefore, in this explanatory, process study, we address the following research question:

$R Q 1$. How can active and engaged membership of a local horizontal social network, characterised by high-intensity cooperation and intermediated by an industry association, afford a set of born globals' accelerated acquisition of international market knowledge and customers?

\section{Research context: the global animation marketplace and local grouping}

The production of animation content generally takes two forms in the contemporary context: traditional drawing, 2D and digital animation that is computer generated, CG. Digital animation involves the combination of traditional artistic drawing skills with modern software technological know-how. The global digital animation industry was propelled to the forefront of the public's imagination with Pixar's breakthrough via hugely successfully movies, both critically and commercially, such as Toy Story, Monsters Inc, Cars, Wall-E and Up. In 2006, Disney took over Pixar for $\$ 7.4 \mathrm{bn}$ to cement its position as the largest animation company in the world. In tandem with the emergence of Pixar as a global success story in movies, the explosion of cable television led to the emergence of dedicated children's TV channels such as Nickelodeon and the Cartoon Network and specialist children's sub-units of the traditional TV networks such as BBC's CBeebies channel. More recently the massive growth in global demand for animated content has been augmented by new requests from online providers such as Netflix and Amazon Prime. These developments have led to a

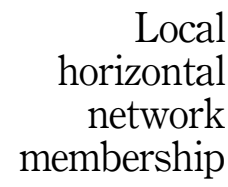

7 
IMR

36,1

significant increase in global demand for animation content which is now bought all around the world even in non-English-speaking countries where the soundtrack is dubbed. Given their small domestic market, insufficient home country audience base and consequent negligible local market potential, the indigenous Irish animation firms must, from inception, rapidly access these customers in the international arena if they wish to survive and grow. Irish animation firms, old and new, now sell animated content to TV channels and movie distributors across the globe in almost 200 countries. By 2018, even the newest of entrants to the Irish sector target overseas markets and sell content in a multiple of ten countries, within two years of inception (www.Animationireland.com).

The Irish animation sector, therefore, represents a particularly insightful context to study born globals for two important reasons. First, given the small domestic market, the indigenous Irish animation firms must, from inception, quickly access customers in the international arena if they wish to commercially release their creative ventures and grow internationally. The vast majority of commissioners of movie and TV animation material are based in multiple countries across the globe, albeit Hollywood USA is the dominant location. Non-English-speaking sites may still purchase content, which is dubbed into the local dialect. Second, it presents a concrete exemplar of a functioning local horizontal network. The animation industry grouping in Ireland exhibits and features high-intensity collaboration rather than competition as the prevailing ethos. This is because animation firms individually pitch for commissions, or are sought out for their product by commissioners, rather than competitively tendering for projects. One firm's success begets higher reputation capital for the collective. The sharing of international market knowledge and intelligence expands the opportunities for all members of the local network of Irish animation firms. Whilst there may be instances of mild competition around content space and the commissioners' eyeballs, the evidence is of an extremely benign form of competition and extensive collaboration. This represents a particular variety of coopetition at the cooperation end of a coopetition spectrum.

\section{Literature review}

A spectrum of coopetition

Coopetition is a term used to describe the paradoxical phenomenon of simultaneous competition and cooperation (Brandenburger and Nalebuff, 1996). Coopetitve behaviour by firms is complicated when rivalries remain the dominant logic and tensions may arise in relationships within the network (Chen, 2008; Fang et al., 2011; Gnyawali and Park, 2011; Raza-Ullah et al., 2014; Gnyawali et al., 2016; Bengtsson et al., 2016). But the extent of rivalry differs along a competition-cooperation spectrum. The more dominant the cooperation logic the less likelihood of opportunistic behaviour that can lead to the emergence of tensions and conflicts between parties. Recent studies on the management of a cooperation-competition paradox has led to a realisation and understanding that rather than being a zero-sum game leading to opportunistic behaviour (Raza-Ullah et al., 2014), firms in certain industry contexts have been found to collaborate with their rivals through the cooperative sharing of resources and capabilities for international growth (Bengtsson and Kock, 2000; Ritala et al., 2014; Crick and Crick, 2016; Crick, 2018). Thus in certain industries, horizontal relationships tend to be less formal and more open to information exchange than vertical economic exchanges (Bengtsson and Kock, 2000). Such cooperative tendencies ultimately rest upon the prevailing dependence between competitors operating in the same industry (Bengtsson and Kock, 2000). For example, Crick (2018) found an industry-wide cooperative mind-set was the key driver encouraging resource and capability sharing activities across competing exporting firms in the New Zealand wine industry.

Coopetition has been evidenced in activities between horizontal firm actors within a network (Bengtsson and Kock, 2000, 2014; Crick, 2018). This leads to a need to distinguish 
between highly competitive and highly cooperative networks (Slotte-Kock and Coviello, 2010) and between forms of exchange relations especially between firms in a horizontal social network.

\section{Horizontal social networks and born global internationalisation}

A social network constitutes a collective whose members connect and communicate for social or instrumental reasons (Brown and Duguid, 2000). Membership of a social network can furnish information access and personal referrals that provide new business opportunities (Burt, 2000). A social network can develop from the continuous construction and reconstruction of ties that become more multiplex and robust over time (Steier and Greenwood, 2000). Social network theory originated in Simmel's (1955) conclusion that a better understanding of social life derives from a deeper understanding of group composition (Slotte-Kock and Coviello, 2010). The economic behaviour of actors in a social system can be determined by the quality of social capital embedded in their relationships, in other words, whether actors are connected through strong or weak ties (Granovetter, 1973, 1985; Uzzi, 1997). Strong ties exist when firms search deeply for solutions in existing close relationships rather than widely for solutions across relationships (Uzzi, 1997). Such relationships within the social network can exhibit tight bonds and high trust between people over a lengthy time duration (Starr and MacMillan, 1990). The high magnitude strength and quality of relationships form social capital amongst strong personal contacts and bonded associates. High social capital allows firms the capacity to generate value from the network of relationships in which they are embedded (Burt, 1992; Nahapiet and Ghoshal, 1998; Adler and Kwon, 2002; Kwon and Adler, 2014). Relational capital refers to the degree to which network relationships engender emotional connections and trustworthiness across members. Trust and goodwill between parties increase motivation to share knowledge (Elango and Pattnaik, 2007). Relational trust in the form of competence and goodwill is based on notions and expectations of "fairness" for all parties (Gulati, 1995). The higher the degree of relational capital, the more mutual trust and the less risk of opportunism featuring between actors in knowledge-sharing activities (Oh et al., 2006; Inkpen and Tsang, 2005). Cooperation especially trumps opportunism when business and personal reputations are on the line (Sasi and Arenius, 2008).

Granovetter (1973) famously challenged the importance of strong ties for firms in social network systems. He argued that as strong ties within a social network interact frequently, much of the information circulating in this social system is redundant and can hinder firm growth. In this view, weak ties are important for firms to connect with as they represent actors who move in social networks other than those of the focal actor (Granovetter, 1985). Through weak ties, a firm can access new information and ideas that lie outside their immediate and close set of contacts. Weak ties were seen to allow wider access to opportunities outside the core web of social relations. They enabled the discovery of opportunities because they serve as bridges to new and different information. Burt (1992) extended this argument by asserting that a tie will provide access to new information and opportunities if it is non-redundant, or if it spans a structural hole. Structural holes across networks represent the absence of ties between actors. Burt (1992) argued that weak ties can fill these "holes" and create some form (although loose) of connectivity between actors that would not have been otherwise there. For international entrepreneurs, these weak ties can expose the entrepreneur to new information, ideas, opportunities and know-how for internationalisation activities (Sharma and Blomstermo, 2003). Rather than a dichotomy, there commonly exists a multiplex mix of strong and weak ties within a social network (Elfring and Hulsink, 2003). In this multiplex view, ties are differentiated not simply by intensity but also by the content of the relationship such as information, knowledge and market intelligence (Jack et al., 2010). 
IMR

36,1

Such multiplex ties in social networks have been found to be particularly important to new ventures seeking to internationalise. Moreover, emerging organisations commonly even lack established business ties (Greve and Salaff, 2003; Evers, 2010; Prashantham and Dhanaraj, 2010). Membership of social networks can, therefore, provide new ventures with access to critical information, resources, knowledge and opportunities globally (Hoang and Antoncic, 2003). Internal social capital can facilitate external international market development through tapping into the knowledge resources of exchange partners (Yli-Renko et al., 2001, 2002).

On the negative side, over-embeddedness in social networks can result in member firms being insulated from other external sources of information and knowledge (Uzzi, 1997; Prashantham and Dhanaraj, 2010). Time and effort spent on nurturing and cementing local horizontal relationships can lead to over-reliance on domestic partners and loss of time that might be better spent on international marketplace development. There can be a trade-off between home relationship development and external marketplace development (Boehe, 2013). An extensive commitment of time and effort is necessary for international market development to overcome liabilities of foreignness (Eden and Miller, 2004). Firms can become distracted from such commitment through the ease of familiar relations with local allies.

\section{Industry associations for horizontal network intermediation and orchestration}

Balancing the tension between over- and under-embeddedness is a role that can be played by an external intermediary, often institutional, such as enterprise promotion state agency. Publicly funded institutional intermediaries have been identified as facilitators in a firm's internationalisation through their support and coordination mechanisms for the industry member firms (Bannò et al., 2014; Sousa and Bradley, 2009). For instance, O'Gorman and Evers (2011) showed how an intermediary state agency played a key role in connecting born global firms to new foreign market customers and provided critical intelligence on global sales opportunities. This support commonly gives rise to the formation of a structured industry association that is organised and coordinated by an institutional intermediary (Chetty and Blankenburg-Holm, 2000).

Industry associations have long been shown to be important fora for the exchange of valuable knowledge, important market information sharing, industry product/service promotion and influencing activities for a set of related member firms (Hadjikhani and Håkansson, 1996; Dhanaraj and Parkhe, 2006). Industry associations are essentially formally structured networks that galvanise the benefits of collective presence and efficiency and orchestrate sales promotions, commonly at international trade shows (Caniels and Romijn, 2003; Evers and Knight, 2008). Despite some caveats (Belso-Martínez, 2006), industry associations, for the most part, are shown to scaffold and supplement knowledge sharing in a horizontal social network, predominantly orchestrated in the local space. Studies have shown that born globals can beneficially avail of membership of their respective industry associations to enhance and support communication, as well as relevant and timely intelligence on foreign markets and customers to rapidly furnish international market opportunities, grow rapidly (Chetty and Blankenburg-Holm, 2000; O'Gorman and Evers, 2011) and generally extend their global reach (Boehe, 2013).

\section{Legitimisation and reputational effects in horizontal networks}

Membership of a horizontal social network can provide communal reputational benefits (Oh et al., 2006). For new market entry, there is a greater need for born global firms to build legitimacy than for their globally established counterparts. As there is limited, or no record of past performance on which they can be judged and evaluated (Zimmerman and Zeitz, 2002), born global ventures may be exposed to liabilities of outsidership (Johanson and Vahlne, 2009; Brouthers et al., 2016), newness and foreignness (Zaheer, 1995). Such liabilities 
are magnified for novice born globals that are in the early stages of their entry into foreign markets (Bangara et al., 2012). The notion of a "legitimacy threshold" can exist below which novice born globals will fail and above, become established (Rutherford and Buller, 2007). Horizontal actors can endow the born global with commercial reputation and legitimacy (O'Gorman and Evers, 2011; Chetty and Blankenburg-Holm, 2000). Through referrals and recommendations, existing horizontal ties can enhance a firm's legitimacy and credibility with others (Zain and Ng, 2006; Ge and Wang, 2013). Strong endorsements from, and associations with legitimised contacts can permit newer firms to piggyback on the reputations of longer-established horizontal network members (Bangara et al., 2012).

\section{Methodology}

\section{Research design}

A case study design has long been considered appropriate for the examination of contemporary issues set in specific contexts (Yin, 2003; Bangara et al., 2012). Context is critical to validate qualitative case studies (Welch et al., 2011). Michailova and Mustaffa (2012) advocate the careful selection of idiosyncratic settings to provide more accurate explanations. Crick and Jones (2000) similarly call for studies that focus on narrowly defined groups of firms to generate more rich data. Using the explanatory case study approach (Eisenhardt, 1989; Yin, 2003), our objective in this study was to investigate how born globals in a local horizontal network leveraged rich social capital to enable their accelerated global market reach and access. This research adheres to well-established practice in the design of case studies (Yin, 2003; Eisenhardt, 1989). Our case study permits a better understanding of the dynamics present within a particular, and a carefully chosen setting (Eisenhardt, 1989) and has strong precedence in studies of accelerated international market entry of born globals (Freeman and Cavusgil, 2007). Moreover, we seek to provide an explication of relational processes in this study and how these evolved over time amongst the studied firms (Pettigrew, 1997; Welch and Paavilainen-Mantymaki, 2014).

Our methodological approach involved examining a case study of a single industry grouping containing multiple proven-to-be born global firms in that conformed to the maxims of a local horizontal social network. This informal social network was found to be mediated by an institutional intermediary in the form of an industry association. The approach is one of theory building and is inductive in nature, rather than seeking generalisability through representativeness. Therefore, we judiciously employed non-probability purposive sampling in choosing our study of Irish animation firms and business setting in the highly globalised animation industry (Saunders et al., 2009). This purposive selection was justified relative to our study's objectives (Robinson, 2014). We used our judgement to carefully identify a critical exemplar of a local horizontal network with an identified need for accelerated access to overseas customers across the globe (Miles and Huberman, 1994; Patton, 2002) on which theory could be built based on the revealed phenomena (Saunders et al., 2009). The screening used in the selection process necessitated that a firm to be studied met the following three criteria. It had to be: indigenous Irish both regarding company registration, residence and principal animated content designed and created in Ireland (some content development is outsourced globally, e.g. to India and South Korea); the core business is the design and production of animation film and/ or TV content, and the firm must have achieved at least 25 per cent international sales in at least two countries within three years from inception (all firms greatly exceeded this minimum criterion of 25 per cent and did so in a shorter period of time than the minimum of three years). Initially, we used the Animation Ireland website (www.animationireland.com) to construct a database of all Irish-based animation companies. We then created a "company information profile" for each of the case companies using secondary sources. Then an introductory telephone communication was made with each case company to explain the purpose of our study and to gain agreement to participate and confirm access to key respondents.

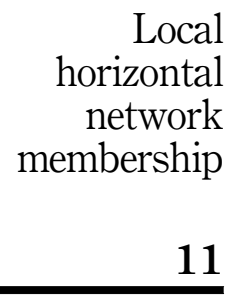


IMR

36,1

\section{Data collection}

Through this screening process, we identified 16 firms that met the three criteria and these constituted our study population (see Table I). All 16 companies agreed to participate in the study and thus we had the involvement of the full population of identified born globals firms in the Irish animation sector. The key primary data holders and respondents were the founders of the animation firms. In total, 20 interviews were conducted over a two-year period with this group as, in the case of four companies, two interviews were conducted with each of the co-founders.

Two further interviews were conducted with key members of the industry trade association, Animation Ireland. This enabled us to get both an insight into their internal orchestration and coordination roles in this local horizontal network and a somewhat independent external perspective on the dynamics and relations between its members.

Data collection was conducted via qualitative semi-structured interviews. The interview schedule of topics that guided and prompted the interview discussion covered a variety of issues on relationships, prior experiences, collaborative activities, the role and benefits of intermediaries, access to international customers, etc. (see Table AI). It was very loosely structured as we wished to probe relations in the network and we wanted the interviewees to speak openly and freely about their experiences and perspectives. We were looking to elicit rich and thick descriptions of behaviours and utilities in the network and how the social capital was leveraged for accelerated global reach. Consistency across all interviews allows for more robust and later cross-firm analyses. All interviewees were briefed in advance on the objectives of the research. The interviewees were guaranteed anonymity so that any contentious issue could be drawn out and discussed if they arose in the course of any interview, e.g., a case of opportunistic behaviour.

The interviewees were positive contributors insofar as they were open and keen to tell their individual and collective stories. Better again, they were natural storytellers in the main and thus, commonly, the interview schedule merely provided a running order for the interviews. The interviewees provided rich narrative data and insight into their prior experiences, relations and activities in rapidly internationalising their businesses.

\begin{tabular}{|c|c|c|c|}
\hline Co. & $\begin{array}{l}\text { Year of } \\
\text { inception }\end{array}$ & $\begin{array}{c}\text { Year of } \\
\text { internationalisation }\end{array}$ & International markets (Locations) \\
\hline 1 & 2003 & 2005 & Canada, Denmark, Hungary, the UK, Sweden \\
\hline 2 & 2002 & 2003 & $\begin{array}{l}\text { Australia, Austria, Canada, Finland, France, Germany, Italy, the UK, } \\
\text { the USA, Spain, Sweden }\end{array}$ \\
\hline 3 & 2000 & 2000 & Australia, Canada, the UK, the USA \\
\hline 4 & 1994 & 1995 & Canada, the UK, the USA \\
\hline 5 & 1999 & 1999 & Holland, the UK, the USA, Singapore \\
\hline 6 & 1999 & 1999 & Belgium, France, Germany, the UK, the USA \\
\hline 7 & 2008 & 2010 & Australia, Canada, Denmark, France, the UK \\
\hline 8 & 2002 & 2002 & $\begin{array}{l}\text { Australia, Canada, Czech Republic, France, Holland, Iceland, India, } \\
\text { Norway, the UK, the USA, Slovenia }\end{array}$ \\
\hline 9 & 2001 & 2001 & Canada, Germany, the UK, the USA \\
\hline 10 & 2003 & 2003 & The USA, France \\
\hline 11 & 1994 & 1994 & France, Germany, Iceland, the UK, the USA \\
\hline 12 & 2010 & 2010 & Canada, the USA \\
\hline 13 & 2004 & 2005 & Australia, Poland \\
\hline 14 & 1995 & 1998 & $\begin{array}{l}\text { Australia, Canada, France, Finland, Germany, India, the UK, the USA, } \\
\text { Taiwan }\end{array}$ \\
\hline 15 & 1988 & 1999 & Australia, France, Germany, the UK, the USA \\
\hline 16 & 2007 & 2008 & The UK, Canada \\
\hline
\end{tabular}

Table I.

Sectoral profile 
Triangulation was conducted through the collation of secondary material in the form of company and industry association websites, business press articles, industry reports, newspaper culture section articles, online podcasts and other published media to provide a richer context for our study. The collection of secondary data on the firms and animation sector in Ireland continued up to the present date. Much media attention is given in Ireland to this sector given its general global business growth. Moreover, there has been a veritable media frenzy surrounding these animation firms given their high-profile international successes in awards ceremonies such as the Oscars and BAFTA.

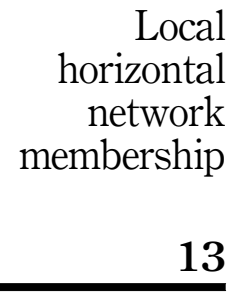

\section{Data analysis}

Our ultimate aim in this study was to build theory on how rich social capital in horizontal networks was developed and leveraged by member firms for accelerated international market access and development (Eisenhardt, 1989; Haley and Boje, 2014, Miles and Huberman, 1994; Pollock and Bono, 2013). The ethos of the analysis of our qualitative data was interpretivist and our broad structure was chronological in our depiction of the evolution of internal network relations and external global market development (Welch et al., 2011). Initially, the interviews were transcribed resulting in almost 300 pages of content from the primary interviews with the 16 firms and two interviews with the institutional intermediary. Data were organised using NVivo for within case analysis and cross-case comparison (Yin, 2003). A case file on each firm was created. For each case subsidiary, we constructed a chronological history of its entry into international markets and how it is accelerated global market presence evolution unfolded. The rich narratives provided by the entrepreneurial animators, who are mostly natural and gifted storytellers, were rigorously analysed through content analysis. We followed the logic of narrative sequence analysis as a technique for theory development (Buttriss and Wilkinson, 2006). Transcripts were manually analysed in a conventional manner to identify and interpret the nature and quality of relations in the network and interpret how this social capital was leveraged for accelerated global market reach and development. Selected quotes were used to illustrate critical insights and particularly apposite evidence. We next combined these case histories and global market evolution to create a chronological evolution of the horizontal network's global market footprint. Subsequently, cross-case analysis of the data was performed, where data were compared and contrasted across the network firms, and particular attention was given to emerging patterns (Miles and Huberman, 1994).

We further employed triangulation of our primary qualitative data and rich narratives from these natural storytellers with secondary data in our analysis to deepen our interpretation of our interview data and enhance the reliability and trustworthiness of our findings (Sobh and Perry, 2005). Specifically, we continuously tracked and collated secondary sources on key events, critical happenings and notable milestones in both the case firms and the horizontal network. In a prolonged reflexive engagement with our data, both primary and secondary, we refined our analysis through successive iterations between theory and data (Ryan and Bernard, 2000; Silverman, 2000).

\section{Findings}

In the beginning: the provenance of internal social capital

The origins of this local horizontal network of member firms are found in the founders' experiences and friendships, principally formed whilst at animation school in a technical art college. Animation skills development and latent artistic talent of the majority of the firms' founders were incubated at two institutes, the Irish School of Animation at Ballyfermot College and the Dun Laoghaire College of Art and Design. These courses not only produced skilled individuals but also, they provided the loci wherein early social bonds and 
IMR

36,1

connections were established between animators who had a collective and shared love of the art and technique of animation. This led to the initial formation of strong bonds, high levels of collegiality and mutual trust amongst members which later would lead to a strong willingness to aid fellow network members in decisions to undertake new venture formation. These early bonds were later cemented as industry connections between animation firm's founders and were to continue throughout the early pioneer and later trans-generational evolution of this local horizontal social network:

I think the friends that we would have made in college would have helped us connect internationally. We have often had job referrals from our classmates in Ballyfermot [...] [...]. Some of the other studios in Dublin would have been formed by guys a few years ahead of us in college. That is why everyone knows and helps each other (Co-Founder, Firm A).

It was common after graduation for animators to work for studios in the important US centre and base of movie and TV studios that is Hollywood. Half of the animation firm founders had international work experience there, in the international animation sector before setting up their own enterprises. These network members have worked in studios such as Pixar-Disney and Warner Bros. These international work experiences gave founders' their early visions of the global animation industry and even some initial access inside the global industry network.

Post start-up, the accelerated internationalisation of the network members was also facilitated by the willingness of members to share contacts forged from their previous industry work experiences. Previous work experience with global studios also provided some early credibility with content commissioners. These contacts in the major studios were maintained and nurtured by network members and proved useful as contacts (and potential future product commissioners) that could be, and later were, passed on and shared amongst all network members:

My main connectors are my connections and that has been established by working there [USA] for three years. As Warner Brothers closed its doors to animation, everybody I know there went to other studios over there so all of a sudden you know a bunch of people at Pixar, Dreamworks and Sony. I go back there every year, and I meet with them. We would stay up to date and keep the network alive and through that, meet new people (Firm B).

The guys at [Firm X] refer to someone they know in a studio they believe would be important for you to talk to (Firm J).

\section{A brave new world: born globalness}

From the early days of the informal formation of this local horizontal social network amongst students of animation, there was an evident collective desire to matter on a global stage. Findings show that artistic talent of founders was combined with enterprise ambitions after graduation. Such pull factors were complemented by further start-up firms that were founded by animators who commonly were pushed into starting a new venture as they did not wish to permanently or even long-term leave their home country to work for the large animation companies overseas, generally in the USA. This was of course beyond the desire to leave their home country for a finite period to gain valuable short- to medium-term work and industry experience. Principally, the pioneer founders set out into the relative unknown on their early forays into the global animation marketplace. Nonetheless, they were filled with both an ambition to succeed on the global stage and a realisation that the confines of the domestic marketplace would not afford them the opportunity to keep their fledgling businesses alive and furnish growth. As expressed in parallel terms by many interviewees, they were born global:

We have always known that Ireland is a small market that can't support the animation we produce, so we have to look abroad (Firm A). 
We never set up for an Irish market at all. The population is too small. We knew straight away our product would need to have international appeal (Firm H).

We weren't making content for Ireland [...]. ever! Animation feature films cost a large amount to make, millions. The Irish market was never going to suffice (Firm B).

Ireland is such a small market [...]. you have to look outside the country (Firm N).

You want to be doing stuff on a global scale, be on screens around the world. Everybody (in the network) wants to be the biggest thing, the next Sponge Bob or Bob the Builder (Firm B).

\section{Local horizontal network membership}

\section{Cartoon Network: rapid global market development via the horizontal social network}

The easy familiarity of the early cemented social bonds in their college days was nurtured and extended into their business relations over time by the network members. As one network member stated:

[Firm X] assisted us a lot by helping us connect abroad. After all, we were all colleagues at college (Firm L).

This high willingness to assist fellow industry competitors was not simply a consequence of bonds of friendship formed as classmates (by the earliest industry entrants). It was also due to the specific industry conditions whereby each firm pitched their ideas for animation features or TV shows to the content purchasers. Though this might be the same pool of customers there was a scope for the purchase decision to be based on the quality of the original pitch which, if liked, was green-lighted. There was ample room on the demand side for several winning pitches. The competition was accordingly benign and trumped by the benefits of cooperative behaviour by these local network members. Thus trust developed amongst all firms in the network, pioneers, early entrants, latecomers and new entrants. Naturally, the strongest bonds existed between the original entrants but newcomers were welcomed into the community with open arms. The collective prevailed over individual self-interest. Strong relational ties were reported to exist between the respective pioneers, then with early entrants. Later, any weaker relational ties with later or new entrants were nurtured to become strong in good time. Network ties are almost inevitably multiplex but the preponderance in this network was strong ties between these local animation firms. This is a congenial network best characterised by placid coopetition. As one founder stated on the high levels of internal network collaboration: "I think it is because we are not all pitching at the same pool and we all have different models" (Founder, Firm D). Another said that "we see them as our friends rather than competition" (Founder, Firm M). The reason behind the extremely benign form of coopetition was suggested by one respondent (Firm I) to be as a result of the nature of the distribution and customer value chain. He claimed that:

We are all one step removed from the (final) consumer. The consumer is the watching audience. We seldom really meet the audience. We are selling to somebody who is then selling to the audience. That's a TV station or a cinema distributor. So that sort of takes the edge off the competition!

Relations are convivial and interactions cordial between members. The pioneers who experienced stellar international successes in the industry, in both audience numbers for their content purchasers and international animation awards, acted as veritable anchors for this social network. Those parties closest to the internal network members recognised and acknowledged this strong propensity to assist, share, guide and mentor. One noted that: "The animation guys are highly collaborative in Ireland [...]. this is a way to start getting connected internationally" (Animation Ireland).

In time, the pioneer international market developers and early follower international market entrants developed both valuable contacts in the international marketplace and important international market knowledge that could be shared with fellow pioneer 
IMR

36,1

network members. There then followed into the local horizontal social network a wave of fresh, late market entrants. Their liability of newness in the international market was mitigated by the willingness of the pioneers to share their contacts and market knowledge. Existing members actively and enthusiastically welcomed these new entrants to their peer social network.

Network members exhibited high levels of "caring and sharing". They were clearly intent on, and seen to leverage social capital for accelerated foreign market knowledge acquisition and entry. The internationally experienced international market pioneers and early local horizontal social network entrants mentored these young firms and were readily available when they sought counsel. Important international market information and global industry contacts were shared. Essential learnings garnered from their successful track record (and mistakes made) in developing product and accessing purchasers were passed on to new network members. One network member respondent stated that "the success of the Irish animation sector is bigger than the sum of its parts" (Firm B). Reciprocity, give and take was expected, and there was a clear absence of opportunistic behaviour by network members that might be injurious to the collective. There featured extensive goodwill trust well beyond competence trust in the local horizontal social network. Network members opened their coveted "contacts books". For example, regarding tangible benefits of information sharing, on occasion when the network member firms have only the resources or capacity to deal with a certain number of ongoing projects they may not be able to avail of all opportunities that may arise, sometimes opportunistically. Such "hot" opportunities are readily shared with fellow network members that may be in a position to execute.

Inherent in this cooperative network was an appreciation that any benefits of sharing valuable, relevant and timely international market information and intelligence strongly outweighed corollary advantages of an isolated "go-it-alone" international market development approach. New or latecomer entrants to the network felt at liberty to seek out market intelligence from incumbents. The original network members were also willing to impart their knowledge even when relational ties were as yet weak. These new members were also socialised on the merits of openness and sharing and the expectations of such mutual sharing and non-opportunistic behaviour. One firm founder commented that "You learn about the need to share each other's resources" (Founder, Firm O). We next show how the network members now began to leverage this internal social capital for an ever more rapid international development through sharing timely and relevant international market intelligence.

The growth of this local social horizontal network continued apace and, over time, more diverse international market knowledge accumulated within the local horizontal social network. Ultimately all boats were seen to rise from the open sharing of valuable international market knowledge: "We support each other to make it happen, that's how we have grown the network" (Founder, Firm C). Even with differential individual firm growth and success in the global marketplace, the willingness to share and assist others' development remained integral within the local horizontal social network. Because of rich internal social capital, they continued to share market knowledge and global industry contacts without feelings of threat or vulnerability. The open, trusting network dynamic also persisted due to members' enduring a sense of security within the local horizontal social network for safe non-vulnerable knowledge sharing with international market-seeking fellow industry members. Newer voices were always welcomed rather than crowded out and while pioneer firms with strong track records of international achievement were obviously more impactful, the newer approaches of late entrants to international market development (e.g. social media) were shared and accepted, thereby avoiding groupthink. Cross-generational learning within the local horizontal network, therefore, was bi-directional but mainly paternalistic. Later entrants to the local horizontal social network continuously learned from the mistakes of the pioneers and early entrants. One example of learning 
related back to us by a pioneer network member that had held its important first full animated feature-length movie premiere in Dublin. The event went undetected in the global marketplace. As a result from the learning from this location mistake, future premiere events took place in overseas markets, mainly in the USA.

Even nascent network members found they could easily cultivate relations even with the most experienced and iconic powerful local horizontal social network members. The founders also learned from and shared their early experiences as novices in the international marketplace, both positive and negative. Fellow pioneer entrants collectively learned from these stories and later shared their learnings with latecomer members of this horizontal social network. "War stories" from early engagements in the global market battlefield of overcoming adversity in the international marketplace, cunningly opening, even breaking down doors, accessing customers, evading gatekeepers, promising looking trails that dried up, etc. were passed on and became part of the local horizontal social network folklore and heritage. Importantly, there was both experiential and congenital learning evident in the network.

This development of rich internal social capital with harmonious community spirit and collaborative intensity within the highly cohesive network was supplemented by the industry association "Animation Ireland", a government-funded representative body tasked with promoting and co-ordinating manifold activities of Ireland's animation enterprises. Animation Ireland's organisational infrastructure was marshalled to supplement its community of member firms' own informal network activities to acquire global market intelligence and make sales internationally. Animation Ireland's personnel possess an intimate knowledge of each animation company in the network and strenuously strove on their behalf for their international success, often behind the scenes. Locally, Animation Ireland's personnel also organised, sponsored and hosted important networking events that complemented the animation network's members more informal social meet-ups as friends and confidantes. More specifically, Animation Ireland organised talks, events, workshops, local conferences at which there was high attendance and wherein market intelligence, information and knowledge was shared openly. This attenuated many liabilities of newness and outsidership for new network members. Membership was thus considered prudent by the study firms as there is perceived to be a collective benefit in sharing information and reducing transaction costs.

As well as providing an important institutional scaffolding for the network locally, Animation Ireland also played a central role in international market development for its members. Animation Ireland was instrumental in showcasing individual member successes of its network members and also for the industry sector as a whole. "We sell the "Animation Ireland' brand in international markets and at trade and industry events. With the growth of the animation sector here (Ireland) in the last number of years, that brand is getting very important internationally for market access" (Animation Ireland). Animation Ireland recommends international trade shows or festivals to member firms, as well as highlighting individuals with whom contact, whilst in attendance, could prove fruitful. The members of the network communally benefit from Animation Ireland's organisation and coordination of activities at international trade shows and film festivals under an umbrella stand. This collective presence bestows further legitimacy and reputational capital on the network of firms which meant that network members could share information on commissioning agents at the events. There is also collective efficiency as the umbrella stand alleviates the expense of individual attendance for network members.

Animation Ireland was also found to target important attendees at these international events and intermediate between agents and its network members: "we do not just have a stand at a trade event, it's a much higher level of engagement" (Animation Ireland). One interviewee recounted Animation Ireland advising that "You should talk to this person, meet that person. They (Animation Ireland) have been excellent" (Firm A). Industry association members recognised and appreciated their efforts: "At Kidscreen 
IMR

36,1

(a large animation tradeshow held in various hosting countries worldwide) they organized a networking event" (Firm E). "There is an event at Annecy in France, and they (Animation Ireland) did a spotlight on Ireland" (Firm C), "At MIPCOM (various hosting countries) they made new connections and unlocked new business opportunities" (Firm A).

Animation Ireland has a wide global network. Key personnel have critical contacts within the content commissioning departments of international movie and TV studios. This means that they can provide valuable international market intelligence that further supplements global market knowledge that exists within the social network. "We (Animation Ireland) meet a huge variety of content producers, sales agents, distributors and broadcasters from many countries". Such direct industry contacts have been nurtured and developed over years of activity and networking in the global animation industry. "They know more people than we do, and they pick out people you should meet so that you don't waste time meeting people that aren't going to do anything for you" (Firm A). "They will set up meetings which kick-start new connections" (Firm C).

As a consequence of their orchestration and intermediation activities, membership of the Animation Ireland industry association consisted of the full population of animation firms producing content for TV and movie commissioners. While membership of the Animation Ireland industry association was naturally voluntary, the extent of engagement expected of, and delivered by members was high. Member firms were actively engaged, rather than holding a passive affiliation with the Animation Ireland.

\section{Oscar Bravo: global reputation effects and collective legitimisation}

Collective legitimacy for the network, that afforded extended global reach and international market access, emanated from credibility gained from the accumulation of individual members' excellent quality original work delivered on time and budget and resultant international awards: "Any company that performs and does well is seen to raise the profile of every company" (Firm D). The reputation of the network grew in the international marketplace over time to the benefit of even nascent members.

Positive "word-of-mouth" gave rise to new international connections and market opportunities via referrals and recommendations of the firms' craft, products and performance in terms of quality of content, timeliness of delivery and on-budget production: "OK, they have managed this one perfectly well, they made a good project, brought it in on time, on schedule" (Firm O). One firm posited that "once you do one job it links to another and so on. Previous work brought us more work than anyone can imagine" (Firm A). Another respondent simply added, "You have to build trust with others, and you only can do this by doing excellent quality work for them and as a result, one job will lead to another" (Firm D). Another stated that: "We're known as a really easy going company to work with [...] we've got quite a good reputation for reliability and just being good budget guys" (Firm C). Individual firm's respective reputational capital development aggregated into a strong reputation for performance and delivery for the network community as a whole. As one interviewee reported, "It reflects well on us" (Firm B).

There was widespread global animation industry content purchasers' confidence in the recommendations of these strong performers. There was a common appreciation amongst network members of their duty of care to all network members, particularly if poor performance followed by a positive recommendation from a fellow network member. Good track records and "earned legitimacy" for individual garnered an "ascribed legitimacy" for the wider network. There was no evidence of harmful or opportunistic behaviour by network members that would have impaired collective legitimacy and be injurious to all members of the local horizontal social network. Each firm willingly provided endorsements, referrals and commendations for network members. Latecomer members could piggyback into international markets via such collective legitimacy. 
The within-industry reputation for quality work was compounded by external industry validation in the form of numerous awards garnered by network members. The reputation of the network was significantly raised when, over a short number of years, six Irish films were nominated for "Best Animation" Oscar awards, including three feature-length productions, The Secret of Kells in 2010, The Song of the Sea in 2015 and The Breadwinner in 2018 (see Table II). This represented a very high water mark for Irish animation as an Oscar nomination has been described as "the best possible endorsement" (Perry, 2010, p. 1).

Such international success in awards ceremonies led to deep and important collective reputation capital for the members of the Irish community of animations. The positive

\section{Local horizontal network membership}

International Success (2010-2018)

Year Award/Nomination

Winner

2010 Oscar Nomination Fipresci Award: 34th Annecy Animation Festival Royal Television Award

2011 Nominations for the BAFTA

BAFTA Award

Arclecchino Award

Special Animation Award: The Novara Cine Film Festival Italy

Best Animation Film Award: Canada International Film Festival

2012 European Producer of the Year: Cartoon Forum

Annecy Nomination

Screenplay Award: The San Francisco Short Film Festival the USA

2013 Nominations for BAFTA

International Emmy Award

Emerald Star Awards at the Cinemagic Film Festival

Tokyo Kinder Film Festival Award

2014 IFTA Awards

SXSW Film Festival Award

Annual Delhi Shorts International Film Festival Award

2015 European Film Award

Satellite Award: Best Animation

Brown Bag Films

Cartoon Saloon

A Man and Ink

Jam Media

Brown Bag Films

Boulder Media

Telegael

Prickly Pear Studios

Jam Media

Giant Animation Studios

Prickly Pear Studios

Brown Bag Films

Boulder Media

Moetion Films

Brown Bag Films

Jam Media

Boulder Media

Cartoon Saloon

Boulder Media

Best Writing in Children's TV Episodes by Writers Guild of Great Britain Brown Bag Films

NAACP Image Award

Nickelodeon Animated Shorts Selection

Brown Bag Films

Mooshku

Wiggleywoo

Daytime Emmy Nominations

IFTA Nominations

UK Film Festival Award

Pulcinella Award

2016 Jameson Empire Award

Kidscreen Summit 2016 Awards

Nominations for the Annie Awards

Nominations for the Children's BAFTA Awards

IFTA Award

International Emmy Kids Award

Emmy Awards at the Annual Daytime Emmy Awards

NAACP Image Award

European Producer of the Year Cartoon Movie

Raindance and Flicker Rhode Island Awards

2017 Nominated for PGA Awards

Brown Bag Films

Brown Bag Films

Brown Bag Films

Table II.

Brown Bag Films

Boulder Media

Wiggleywoo

Moetion Films

018 Oscar Nomination

Nominations for the BAFTA

International success

(2010-2018) 
IMR

36,1

reputation effects for all network members from individual member's successes are illustrated clearly in the following comments from two respondents:

"The Oscar nominations have benefited everybody, it puts Ireland on the map and portrays this is a place of good quality" and "Ireland has had many Oscar nominations [...] Internationally they believe there is something creative about what is in the water in Ireland that no amount of money can buy" (Founder of Firm E).

Such reputational capital was converted by local horizontal social network members into tangible payoffs. The legitimisation gained from these achievements and successes led to the increased commissioning of product internationally across the member firms. This enhances access opportunities for the entire network as information and contacts are freely shared and market knowledge disseminated throughout the network: "Doors are opened through awards" (Firm B).

We now proceed in the paper to discuss some theoretical implications of the revealed phenomena that we have reported in this idiosyncratic study context.

\section{Discussion}

In this explanatory process study, we illustrated how active membership of a cooperative local horizontal network affords accelerated internationalisation. We paid particular attention to how the network members leveraged rich internal social capital for their acquisition of foreign market knowledge and rapid global market development, yielding born globalness for the highly collaborative network members firms. For our studied born global firms, active insidership of this cooperative local network mitigated certain liabilities of outsidership in foreign markets. This was possible as the industry grouping was characterised by benign competition at the cooperative extremity of a coopetition spectrum. Contrary to Granovetter's (1973) and Burt's (1992) arguments on weak ties, our findings show that strong horizontally connected firm ties within the industry had the ability to connect the member firms to foreign markets and help bridge structural holes between them and their foreign customers and partners. In this horizontal setting exhibiting mainly strong ties and close relations, the high-level relational embeddedness of trust, benevolence and solidarity discouraged opportunistic behaviour or furtive activities by any firms in the collective. The extent of competition was low, even negligible, and strongly marked by collaboration over the rivalry. This is a particular form of coopetition and supports the view that coopetition between firms can be frequently explained by the prevailing dependence between competitors operating in the same industry (Bengtsson and Kock, 2000; Crick, 2018). Based on this interdependency across horizontal actors and on similarities in resources, interests and challenges, born globals in the Irish animation sector act as valuable partners for sharing costs and risks.

Engaged membership of a local horizontal social network led to rapid accumulation and transferral of knowledge, which afforded accelerated global reach and the acquisition of international market knowledge and customers for these affiliated born global firms. The firms in the network exploited their local ties, collective experiences and communal legitimacy to access new international market contacts and opportunities. We showed that the local horizontal social network featured high-intensity collaboration with frequent open communication, timely and relevant international market information pooling and provision, reciprocal benefits, benevolent interactions, strong internal ties and bonds between members. We further explained how this active and highly engaged network membership activity conferred important international market knowledge that further accumulated and evolved within the local horizontal social network. Warm intra-network personal connections built goodwill and trust in the local domain that alleviated many liabilities of newness (Mudambi and Zahra, 2007), foreignness (Zaheer, 2002) and outsidership (Johanson and Vahlne, 2009) for 
pioneer and latecomer members of this social network in their ambitions and efforts to rapidly access international markets early in their existence. The international market presence of the local horizontal social network expands collectively to the benefit of all members. While some studies have shown the existence of negative effects (Milanov and Fernhaber, 2014) or mixed benefits of over-emphasis on local relationships (Boehe, 2013; Prashantham and Birkinshaw, 2015), we illustrated the strongly positive benefits for a local horizontal social network that exhibits high-intensity collaboration.

Our findings on internal social capital refine studies that point to adverse impacts of close social relations and ties between local network members on international market performance. Strong social ties in the home country have been shown to hinder early SME international performance (Milanov and Fernhaber, 2014; Prashantham and Birkinshaw, 2015 ) in that an excessive internal focus may result in isolation from external valuable sources of information (Uzzi, 1997; Goerzen, 2007). However, contrary to this view, we found that this set of connected born globals was highly dependent on their strong horizontal social ties locally and close in-group relations in the initial and growth stages of international market development. We subscribe to and extend Boehe's (2013) qualified illustration of the positive impact of strong local network relations for internationalisation rather than those close social bonds being an impediment that suppresses international market opportunities. Strong ties evolve from weak ties and at any discrete point in time there are multiple ties. Whilst multiplexity is the norm in networks (Elfring and Hulsink, 2003) the tendency in this network was towards strengthening of ties and the utility of developed strong ties.

Association with, and learnings from pioneers' international experiences was also found to engender confidence in latecomers that they could emulate the successes of pioneer network members in international markets. Our findings illustrated that there was both experiential and congenital learning occurring in the network. We showed how a horizontal social network could cumulatively accrue a stock of international personal and business contacts derived and collated from each founder's prior international and industry experiences (Crick and Jones, 2000; McDougall et al., 2003). Born global entrepreneurs' deck of former foreign business contacts, acquired through prior international market exposure and previous industry experience, constitute key sources of foreign market knowledge on customers (Chetty and Blankenburg-Holm, 2000). Leveraging these communal global contacts is particularly useful for born globals (Jones et al., 2011), which typically possess limited resources for desired rapid international growth.

Our study also illustrated how each firm's individual success benefits all local network members as market knowledge expands and reputation capital is shared. Our findings showed that the international awards garnered by individual network members drove the common good regarding enhanced credibility and authenticity and shared recognition in line with common group identity theory (O'Gorman and Evers, 2011). Our study also showed the merits and assistance of endorsements, referrals and recommendations from credible associates to enhance a firm's legitimacy with international customers (Zain and $\mathrm{Ng}, 2006$; Ge and Wang, 2013). We further explained how communal legitimacy afforded rapid market entry for latecomers to the network through piggybacking on the achievements of, and endorsements from pioneer network members.

Our study also reinforced previous research that showed that an institutional intermediary in the form of an industry association can supplement the social network's own set of international contacts. Chetty and Blankenburg-Holm (2000) identified an industry association as especially helpful for brokering important relationships for small firms to internationalise rapidly. We challenge the findings of Belso-Martínez (2006) who conversely found that an institutional intermediary's role was insignificant for rapidly internationalising SMEs. The industry association in our study was also shown to be highly

\section{Local horizontal network membership}


IMR

36,1

22

effective at orchestrating the communal internationalising activities and infrastructure of this local horizontal social network. This provided an institutional scaffolding for these born global ventures to enhance their collective presence and global reach into international markets. In line with previous studies (Ellis, 2000; O'Gorman and Evers, 2011), our findings support the view that institutional intermediaries utilise their resources to mobilise, coordinate, facilitate and encourage interaction and sharing amongst their industry association member firms leading to accelerated international market development. In particular, in our study, the industry association was found to have a position of formalised centrality as this is important in the facilitation of potential international customer introductions, the organisation of the attendance of these born globals at global trade forums (Caniels and Romijn, 2003) and the provision of relevant and timely international market information. In our study, the industry association acted as both a connector to external international purchasing decision makers and coordinator of the internal network that facilitated the internationalisation of this set of born globals. The industry association was shown to assume much of the intangible coordination and transaction costs across the network. We found that there were clear benefits in evidence from the collective presence at international events that expanded customer access and engendered collective efficiency from shared costs. Ultimately, in this study, we discovered complementarity between membership of an informal local horizontal social network that exhibits internal high-intensity collaboration and membership of a formalised industry association by an external network coordinator.

Our study finds that the tripartite combination of a born global's local horizontal network relationships and social capital, collective founders' cumulative international experiences and communal reputational legitimacy effects can be leveraged by network members to extend their global reach and international market opportunities from inception (see Figure 1).

\section{Conclusions}

High-intensity collaborative inter-firm relationships embedded in a local horizontal social network, and mediated in part by an institutional actor, can be leveraged by a set of born globals, collectively but differentially, for accelerated acquisition of international market knowledge and global customers. In essence, firms with an insufficient domestic market size and inconspicuous global presence can organise as a collective to their individual and communal benefit in their international marketplace through sharing valuable and timely international market intelligence.

Figure 1.

Local horizontal social networks for accelerated global international market development

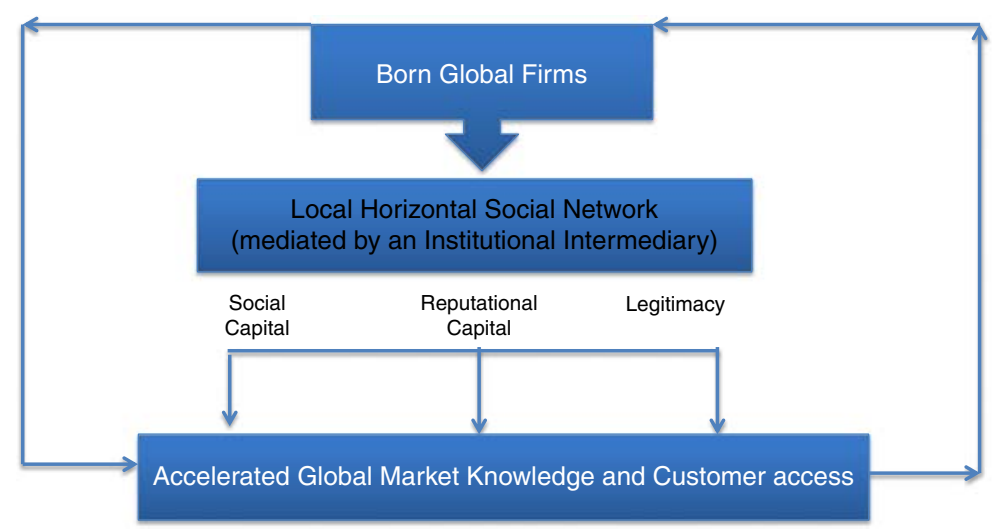


We principally contribute to the emerging stream of literature that explains how local relations afford international market development (Fernhaber et al., 2008; Leonidou et al., 2010; Yu et al., 2011; Andersson et al., 2013; Boehe, 2013). We explain how, under certain coopetition conditions, local connectivity affords and expands international connectivity. Previous studies identified that an excessive or over-concentration on local network relationships may hinder, or reduce the benefits of internationalisation (Boehe, 2013; Milanov and Fernhaber, 2014; Prashantham and Birkinshaw, 2015). However, in our qualitative study, we rather show how rich internal social capital grown and embedded in the horizontal network of born global firms bestows accrued benefits on all its members and in turn, affords wider global reach into international markets. We provide a richer understanding of the influence of local horizontal networks on born global internationalisation and, more so, how active membership of a such a social horizontal network can lead to high-intensity collaborative relations enabling rapid market acceleration of born globals. Further, trust in high-collaborative networks laid the foundations for expanded international market knowledge that could be widely shared amongst network members.

We also complementarily present a nuanced theory of coopetition at the cooperation extremity of the spectrum (Bengtsson and Kock, 2000; Chen, 2008; Fang et al., 2011; Gnyawali and Park, 2011; Raza-Ullah et al., 2014; Gnyawali et al., 2016; Bengtsson et al., 2016; Bengtsson and Kock, 2014; Crick, 2018). In our particular study context, cooperation between network members extends to collective efforts to create and share global market intelligence via open and rich exchange of information and knowledge.

We make some further contributions to international marketing and international entrepreneurship theory. We contribute to extant theory on how born global firms can develop their international marketing capabilities (Evers et al., 2012) and create new customer contacts in overseas markets. We also extend theory on how network coordination by an institutional intermediary, such as an industry association, affords expanded global reach and international market opportunities (Ellis, 2000; Chetty and Blankenburg-Holm; O'Gorman and Evers, 2011). Third, we add to the theory on how social and reputational capital accumulates in a horizontal social network locally and is leveraged by members to extend their global reach into international markets (Oh et al., 2006; Bangara et al., 2012). We lastly develop a theory on how active insidership of a horizontal social network locally can diminish the liability of outsidership in international markets (Johanson and Vahlne, 2009).

\section{Managerial implications}

The findings of this research have implications for international marketing practice. Our study has lessons for member firms that have the scope to be more cooperative in sharing international market intelligence for accelerated global market entry and reach. For firms that want to rapidly access international markets from their earliest days of existence market knowledge is a critical, but often missing resource. This can commonly be jealously guarded by incumbent competitors. However, where competitive conditions in an industry mean that sharing information and knowledge has mutual benefits that outweigh secrecy from rivals, managers should develop and nurture trusting relations and stridently avoid opportunistic behaviours that dent confidence in their trustworthiness from other network members. Any loss of trust would mean sanctions and even exclusion from the rich information and reputation capital that a social network may accrue and which then may be leveraged for an accelerated global market reach.

\section{Study limitations and future research directions}

Despite our contributions to extant theory, our study is not without its limitations. The high degree of market intelligence sharing in evidence in this idiosyncratic horizontal social 
network is uncommon in international business. More usually, intra-industry members zealously protect their important customer contacts due to competitive pressures. While we aimed to generalise to theory development, future research on local firms wishing to rapidly enter international markets could look at differing contexts along the coopetition spectrum, in other industries and in other national cultures. Such future research could usefully endeavour to test our theoretical framework through further qualitative studies in these varieties of settings beyond the idiosyncratic, distinctive and relatively unique local network of this study.

\section{References}

Adler, P.S. and Kwon, S.-W. (2002), "Social capital: prospects for a new concept", Academy of Management Review, Vol. 27 No. 1, pp. 17-40.

Andersson, S., Evers, N. and Griot, C. (2013), "Local and international networks in small firm internationalization: cases from the Rhone-Alpes medical technology regional cluster", Entrepreneurship and Regional Development, Vol. 25 Nos 9/10, pp. 867-888.

Bangara, A., Freeman, S. and Schroder, W. (2012), "Legitimacy and accelerated internationalisation: an Indian perspective", Journal of World Business, Vol. 47 No. 4, pp. 623-634.

Bannò, M., Piscitello, L. and Varum, C.A. (2014), "The impact of public support on SMEs' outward FDI: evidence from Italy", Journal of Small Business Management, Vol. 52 No. 1, pp. 22-38.

Belso-Martínez, J.A. (2006), "Do industrial districts influence export performance and export intensity? Evidence for Spanish SMEs' internationalisation process”, European Planning Studies, Vol. 14 No. 6, pp. 791-810.

Bengtsson, M. and Kock, S. (2000), "Coopetition in business networks: to cooperate and compete simultaneously", Industrial Marketing Management, Vol. 29 No. 5, pp. 411-426.

Bengtsson, M. and Kock, S. (2014), "Coopetition - quo vadis? Past accomplishments and future challenges”, Industrial Marketing Management, Vol. 43 No. 2, pp. 180-188.

Bengtsson, M., Raza-Ullah, T. and Vanyushyn, V. (2016), "The coopetition paradox and tension: the moderating role of coopetition capability", Industrial Marketing Management, Vol. 53 No. 1, pp. 19-30.

Boehe, D. (2013), "Collaborate at home to win abroad: how does access to local networks influence export behaviour", Journal of Small Business Management, Vol. 51 No. 2, pp. 167-182.

Brandenburger, A.M. and Nalebuff, B.J. (1996), Co-Opetition: A Revolutionary Mind-Set That Combines Competition and Cooperation in the Marketplace, Harvard Business School Press, Boston, MA.

Brouthers, K.D., Geisser, K.D. and Rothlauf, F. (2016), "Explaining the internationalization of ibusiness firms", Journal of International Business Studies, Vol. 47 No. 5, pp. 513-534.

Brown, J.S. and Duguid, P. (2000), The Social Life of Information, Harvard Business School Press, Boston, MA.

Burt, R. (1992), Structural Holes: The Social Structure of Competition, Harvard University Press, Cambridge, MA.

Burt, R.S. (2000), "The network structure of social capital", in Sutton, R.I. and Sutton, B.M.S. (Eds), Research in Organizational Behaviour, Vol. 22, JAI Press, Chicago, IL, pp. 1-83.

Buttriss, G. and Wilkinson, I. (2006), "Using narrative sequence methods to advance international entrepreneurship theory”, Journal of International Entrepreneurship, Vol. 4 No. 4, pp. 157-174.

Caniels, M.C.J. and Romijn, H.A. (2003), "SME clusters, acquisition of technological capabilities and development: concepts, practice and policy lessons", Journal of Industry, Competition and Trade, Vol. 3 No. 3, pp. 187-210.

Cavusgil, S.T. and Knight, G. (2015), "The born global firm: an entrepreneurial and capabilities perspective on early and rapid internationalisation”, Journal of International Business Studies, Vol. 46 No. 1, pp. 3-16. 
Chen, M.J. (2008), "Reconceptualizing the competition - cooperation relationship? A transparadox perspective", Journal of Management Inquiry, Vol. 17 No. 4, pp. 288-304.

Chetty, S.K. and Blankenburg-Holm, D. (2000), "Internationalization of small to medium-sized manufacturing firms: a network approach", International Business Review, Vol. 9 No. 1, pp. 77-93.

Coviello, N. and Munro, H. (1997), "Network relationships and the internationalisation process of small software firms", International Business Review, Vol. 6 No. 4, pp. 361-386.

Coviello, N.E. (2015), "Re-thinking research on born globals", Journal of International Business Studies, Vol. 46 No. 1, pp. 17-26.

Crick, D. (2009), "The internationalisation of born global and international new venture SMEs", International Marketing Review, Vol. 26 Nos 4/5, pp. 453-476.

Crick, D. and Crick, J.M. (2016), "Coopetition at the sports marketing/entrepreneurship interface: a case study of a Taekwondo organisation”, Marketing Intelligence \& Planning, Vol. 34 No. 2, pp. 169-187.

Crick, D. and Jones, M.J. (2000), "Small high-technology firms and international high technology markets", Journal of International Marketing, Vol. 8 No. 2, pp. 63-85.

Crick, D. and Spence, M. (2005), "The internationalisation of 'high performing' UK high-tech SMEs: a study of planned and unplanned strategies", International Business Review, Vol. 14 No. 2, pp. 167-185.

Crick, J.M. (2018), "The facets, antecedents and consequences of coopetition: an entrepreneurial marketing perspective", Qualitative Market Research: An International Journal, Vol. 21 No. 2, pp. 253-272.

Dhanaraj, C. and Parkhe, A. (2006), "Orchestrating innovation networks", Academy of Management Review, Vol. 31 No. 3, pp. 659-669.

Eden, L. and Miller, S.R. (2004), "Distance matters: liability of foreignness, institutional distance and ownership strategy", in Hitt, M. and Cheng, J. (Eds), Advances in International Management, Vol. 16, Elsevier, New York, NY, pp. 187-221.

Eisenhardt, K. (1989), "Building theories from case study research", Academy of Management Review, Vol. 14 No. 4, pp. 532-550.

Elango, B. and Pattnaik, C. (2007), "Building capabilities for international operations through networks: a study of Indian firms", Journal of International Business Studies, Vol. 38 No. 4, pp. 541-555.

Elfring, T. and Hulsink, W. (2003), "Networks in entrepreneurship: the case of high-technology firms", Small Business Economics, Vol. 21 No. 4, pp. 409-422.

Ellis, P. (2000), "Social ties and foreign market entry", Journal of International Business Studies, Vol. 31 No. 3, pp. 443-470.

Ellis, P.D. and Pecotich, A. (2001), "Finding international exchange partners: the role of social ties", Global Focus, Vol. 13 No. 2, pp. 121-133.

Etemad, H. (2004), "Internationalization of small- and medium-sized enterprises: a grounded theoretical framework and an overview", Canadian Journal of Administrative Sciences, Vol. 21 No. 1, pp. 1-21.

Evers, N. (2010), "Factors influencing the internationalisation of new ventures in the Irish aquacultural industry: an exploratory study", Journal of International Entrepreneurship, Vol. 8 No. 4, pp. 392-416.

Evers, N. (2011), "Exploring market orientation in new export ventures", International Journal of Entrepreneurship and Innovation Management, Vol. 13 Nos 3/4, pp. 357-376.

Evers, N. and Knight, J. (2008), "Trade shows and small firm internationalisation: a network perspective”, International Marketing Review, Vol. 25 No. 5, pp. 544-562.

Evers, N. and O'Gorman, C. (2011), "Improvised internationalisation in new ventures: the role of prior knowledge and networks", Entrepreneurship and Regional Development: an International Journal, Vol. 7 No. 7, pp. 549-574. 
IMR

36,1

Evers, N., Andersson, S. and Hannibal, M. (2012), "Stakeholders and marketing capabilities in international new ventures: evidence from Ireland, Sweden, and Denmark", Journal of International Marketing, Vol. 20 No. 4, pp. 46-71.

Fang, R.S., Chang, Y.S. and Peng, Y.C. (2011), "Dark side of relationships: a tensions-based view", Industrial Marketing Management, Vol. 40 No. 5, pp. 774-784.

Fernhaber, S.A., Gilbert, B.A. and McDougall, P.P. (2008), "International entrepreneurship and geographic location: an empirical examination of new venture internationalisation", Journal of International Business Studies, Vol. 39 No. 2, pp. 267-290.

Freeman, S. and Cavusgil, S.T. (2007), "Toward a typology of commitment states among managers of born-global firms: a study of accelerated internationalisation", Journal of International Marketing, Vol. 15 No. 4, pp. 1-40.

Ge, G.L. and Wang, H.Q. (2013), "The impact of network relationships on internationalisation process: an empirical study of Chinese private enterprises", Asia Pacific Journal of Management, Vol. 30 No. 4, pp. 1169-1189.

Gnyawali, D.R. and Park, B.J.R. (2011), "Co-opetition between giants: collaboration with competitors for technological innovation”, Research Policy, Vol. 40 No. 5, pp. 650-663.

Gnyawali, D.R., Madhavan, R., He, J. and Bengtsson, M. (2016), "The competition-cooperation paradox in inter-firm relationships: a conceptual framework", Industrial Marketing Management, Vol. 53 No. 1, pp. 7-18.

Goerzen, A. (2007), "Alliance networks and firm performance: the impact of repeated partnerships", Strategic Management Journal, Vol. 28 No. 5, pp. 487-509.

Granovetter, M.S. (1973), “The strength of weak ties”, American Journal of Sociology, Vol. 78 No. 6, pp. 1360-1380.

Granovetter, M.S. (1985), "Economic action and social structure: the problem of embeddedness", American Journal of Sociology, Vol. 91 No. 3, pp. 481-510.

Greve, A. and Salaff, J.W. (2003), "Social networks and entrepreneurship", Entrepreneurship Theory and Practice, Vol. 28 No. 1, pp. 1-22.

Gulati, R. (1995), "Does familiarity breed trust? The implications of repeated ties for contractual choice in alliances", Academy of Management Journal, Vol. 38 No. 1, pp. 85-112.

Hadjikhani, A. and Håkansson, H. (1996), "Political actions in business networks: a Swedish case", International Journal of Research in Marketing, Vol. 13 No. 5, pp. 431-447.

Haley, U. and Boje, D. (2014), "Storytelling the internationalization of the multinational enterprise", Journal of International Business Studies, Vol. 45 No. 9, pp. 1115-1132.

Hoang, H. and Antoncic, B. (2003), "Network-based research in entrepreneurship: a critical review", Journal of Business Venturing, Vol. 18 No. 2, pp. 165-187.

Ibeh, K.I.N. and Kasem, L. (2011), "The network perspective and the internationalisation of small- and medium-sized software firms from Syria”, Industrial Marketing Management, Vol. 40 No. 3, pp. 358-367.

Inkpen, A.C. and Tsang, E.W.K. (2005), "Social capital, networks, and knowledge transfer”, Academy of Management Review, Vol. 30 No. 1, pp. 146-165.

Jack, S., Moult, S., Anderson, A. and Dodd, S. (2010), “An entrepreneurial network evolving: patterns of change”, International Small Business Journal, Vol. 28 No. 4, pp. 315-337.

Johanson, J. and Vahlne, J.-E. (2009), "The Uppsala Internationalisation Process Model revisited: form liability of foreignness to liability of outsidership", Journal of International Business Studies, Vol. 40 No. 9, pp. 1-21.

Jones, M.V., Coviello, N. and Tang, Y.K. (2011), "International entrepreneurship research (1989-2009): a domain ontology and thematic analysis", Journal of Business Venturing, Vol. 26 No. 6, pp. 632-659.

Knight, G. and Cavusgil, S. (1996), "The born global firm: a challenge to traditional internationalisation theory", Advances in International Marketing, Vol. 8, pp. 11-26. 
Kwon, S.W. and Adler, P.S. (2014), "Social capital: maturation of a field of research", Academy of Management Review, Vol. 39 No. 4, pp. 412-422.

Leonidou, L.C., Katsikeas, C.S. and Coudounaris, D.N. (2010), "Five decades of business research into exporting: a bibliographic analysis", Journal of International Management, Vol. 16 No. 1, pp. 78-91.

Loane, S. and Bell, J. (2006), "Rapid internationalisation among entrepreneurial firms in Australia, Canada, Ireland and New Zealand: an extension to the network approach", International Marketing Review, Vol. 23 No. 5, pp. 467-485.

McDougall, P.P., Oviatt, B.M. and Shrader, R.C. (2003), "A comparison of international and domestic new ventures", Journal of International Entrepreneurship, Vol. 1 No. 1, pp. 59-82.

Michailova, S. and Mustaffa, Z. (2012), "Subsidiary knowledge flows in multinational corporations: research accomplishments, gaps, and opportunities", Journal of World Business, Vol. 47 No. 3, pp. 383-396.

Milanov, H. and Fernhaber, S.A. (2014), "When do domestic alliances help ventures abroad? Direct moderating effects from a learning perspective", Journal of Business Venturing, Vol. 29 No. 3, pp. 377-391.

Miles, M.B. and Huberman, A.M. (1994), Qualitative Data Analysis: An Expanded Sourcebook, 2nd ed., Sage, Thousand Oaks, CA.

Mudambi, R. and Zahra, S.A. (2007), "The survival of international new ventures", Journal of International Business Studies, Vol. 38 No. 2, pp. 333-352.

Nahapiet, J. and Ghoshal, S. (1998), "Social capital, intellectual capital, and the organisational advantage", Academy of Management Review, Vol. 23 No. 2, pp. 242-266.

O'Gorman, C. and Evers, N. (2011), "Network intermediaries in the internationalisation of new firms in peripheral regions", International Marketing Review, Vol. 28 No. 4, pp. 340-364.

Oh, H., Labianca, G. and Chung, M.H. (2006), "A multilevel model of group social capital”, Academy of Management Review, Vol. 31 No. 3, pp. 569-582.

Patton, M.Q. (2002), Qualitative Research and Evaluation Methods, 3rd ed., Sage Publications, Thousand Oaks, CA.

Perry, S. (2010), "Irish times - Irish film-makers in Oscar Mix", available at: www.irishtimes.com/ newspaper/breaking/2010/0202/breaking66pf.html (accessed 4 February 2016).

Pettigrew, A.M. (1997), “What is a processual analysis?”, Scandinavian Journal of Management, Vol. 13 No. 4, pp. 337-348.

Pollock, T. and Bono, J. (2013), "From the editors being Scheherazade: the importance of storytelling in academic writing", Academy of Management Journal, Vol. 56 No. 3, pp. 629-634.

Prashantham, S. and Birkinshaw, J. (2015), "Choose your friends carefully: home-country ties and new venture internationalisation", Management International Review, Vol. 55 No. 2, pp. 207-234.

Prashantham, S. and Dhanaraj, C. (2010), "The dynamic influence of social capital on the international growth of new ventures", Journal of Management Studies, Vol. 47 No. 6, pp. 967-994.

Raza-Ullah, T., Bengtsson, M. and Kock, S. (2014), "The coopetition paradox and tension in coopetition at multiple levels", Industrial Marketing Management, Vol. 43 No. 2, pp. 189-198.

Ritala, P., Golnam, A. and Wegmann, A. (2014), "Coopetition-based business models: the case of Amazon.com”, Industrial Marketing Management, Vol. 43 No. 2, pp. 236-249.

Robinson, O.C. (2014), "Sampling in interview-based qualitative research: a theoretical and practical guide", Qualitative Research in Psychology, Vol. 11 No. 1, pp. 25-41.

Ruokonen, M., Nummela, N., Puumalainen, K. and Saarenketo, S. (2008), "Market orientation and internationalization in small software firms", European Journal of Marketing, Vol. 42 Nos 11/12, pp. 1294-1315.

Rutherford, M.W. and Buller, P.F. (2007), "Searching for the legitimacy threshold", Journal of Management Inquiry, Vol. 16 No. 1, pp. 78-92. 
IMR

36,1

Ryan, G.W. and Bernard, H.R. (2000), "Data management and analysis methods", in Denzin, N.K. and Lincoln, Y.S. (Eds), Handbook of Qualitative Research, 2nd ed., Sage, Thousand Oaks, CA, pp. 769-802.

Sasi, V. and Arenius, P. (2008), "International new ventures and social networks: advantage or liability?", European Management Journal, Vol. 26 No. 3, pp. 6400-6411.

Saunders, M.N.K., Thornhill, A. and Lewis, P. (2009), Research Methods for Business Students, 5th ed., Prentice Hall, FT, Harlow.

Sepulveda, F. and Gabrielsson, M. (2013), "Network development and firm growth: a resource-based study of B2B born globals", Industrial Marketing Management, Vol. 42 No. 5, pp. 792-804.

Sharma, D. and Blomstermo, A. (2003), "The internationalisation process of born globals: a network view”, International Business Review, Vol. 12 No. 6, pp. 739-753.

Silverman, D. (2000), Doing Qualitative Research: A Practical Handbook, Sage, London.

Simmel, G. (1955), Conflict and the Web of Group-Affiliations, The Free Press, New York, NY.

Slotte-Kock, S. and Coviello, N. (2010), "Entrepreneurship research on network processes: a review and ways forward", Entrepreneurship Theory and Practice, Vol. 34 No. 1, pp. 31-57.

Sobh, R. and Perry, C. (2005), "Research design and data analysis in realism research", European Journal of Marketing, Vol. 40 Nos 11/12, pp. 1194-1209.

Sousa, C.M.P. and Bradley, F. (2009), "Effects of export assistance and distributor support on the performance of SMEs the case of Portuguese export ventures", International Small Business Journal, Vol. 27 No. 6, pp. 681-701.

Starr, A.S. and MacMillan, I.C. (1990), "Resource cooptation via social contracting resource acquisition strategies for new resources", Strategic Management Journal, Vol. 11, pp. 79-92.

Steier, L. and Greenwood, R. (2000), "Entrepreneurship and the evolution of angel financial networks", Organization Studies, Vol. 21 No. 1, pp. 163-192.

Theodorakopoulos, N. and Figueira, C. (2012), "What can situated learning theory tell us about leading to develop organisational learning capabilities for entrepreneurial performance? Lessons from a knowledge-intensive small firm”, Thunderbird International Business Review, Vol. 54 No. 6, pp. 859-873.

Uzzi, B. (1997), "Social structure and competition in interfirm networks: the paradox of embeddedness", Administration Science Quarterly, Vol. 42 No. 1, pp. 35-67.

Welch, C. and Paavilainen-Mantymaki, E. (2014), "Putting process (back) in: research on the internationalization process of the firm", International Journal of Management Reviews, Vol. 16 No. 1, pp. 2-23.

Welch, C., Piekkari, R., Plakoyiannaki, E. and Paavilainen-Mäntymäki, E. (2011), “Theorising from case studies: towards a pluralist future for international business research", Journal of International Business Studies, Vol. 42 No. 5, pp. 740-762.

Yin, R. (2003), Case Study Research: Design and Methods, 3rd ed., Sage, Newbury Park, CA.

Yli-Renko, H., Autio, E. and Sapienza, H.J. (2001), "Social capital, knowledge acquisition, and knowledge exploitation in young technology-based firms", Strategic Management Journal, Vol. 22 Nos 6/7, pp. 587-613.

Yli-Renko, H., Autio, E. and Tontti, V. (2002), "Social capital, knowledge, and the international growth of technology-based new firms", International Business Review, Vol. 11 No. 3, pp. 279-304.

Yu, J., Gilbert, B.A. and Oviatt, B.M. (2011), "Effects of alliances, time and network cohesion on the initiation of foreign sales by new ventures", Strategic Management Journal, Vol. 32 No. 4, pp. 424-446.

Zaheer, S. (1995), "Overcoming the liability of foreignness", Academy of Management Journal, Vol. 38 No. 2, pp. 341-363.

Zaheer, S. (2002), "The liability of foreignness, redux: a commentary", Journal of International Management, Vol. 8 No. 3, pp. 351-358. 
Zahra, S., Ireland, R. and Hitt, M. (2000), "International expansion by new venture firms: international diversity, mode of market entry, technological learning, and performance", Academy of Management Journal, Vol. 43 No. 5, pp. 925-950.

Zain, M. and Ng, S.I. (2006), "The impacts of network relationships on SMEs' internationalisation process", Thunderbird International Business Review, Vol. 48 No. 2, pp. 183-205.

\section{Local horizontal network membership}

Zimmerman, M.A. and Zeitz, G.J. (2002), "Beyond survival: achieving new venture growth by building legitimacy", Academy of Management Review, Vol. 27 No. 3, pp. 414-432.

\section{Further reading}

Burt, R. (1997), "The contingent value of social capital”, Administrative Science Quarterly, Vol. 42 No. 2, pp. 339-365.

Coviello, N. (2006), "The network dynamics of international new ventures", Journal of International Business Studies, Vol. 37 No. 5, pp. 713-731.

Crick, D. and Crick, J.M. (2014), "The internationalisation strategies of rapidly internationalizing high-tech SMES: Planned and unplanned activities”, European Business Review, Vol. 26 No. 5, pp. 421-448.

Oviatt, B. and McDougall, P. (1994), "Toward a theory of international new ventures", Journal of International Business Studies, Vol. 25 No. 1, pp. 45-64.

Vahlne, J.E. and Johanson, J. (2013), "The Uppsala model on evolution of the multinational business enterprise - from internalization to coordination of networks", International Marketing Review, Vol. 30 No. 3, pp. 189-210.

(The Appendix follows overleaf.) 


\section{Appendix}

\begin{tabular}{|c|c|}
\hline Research domain & Probing's \\
\hline \multirow[t]{4}{*}{ Company background } & Founder(s) \\
\hline & Year of inception \\
\hline & Produce \\
\hline & Employee numbers - contract and fulltime \\
\hline \multirow[t]{5}{*}{ Founders' experience } & Education/training \\
\hline & International work experience \\
\hline & Firm(s) \\
\hline & Country(ies) \\
\hline & Duration \\
\hline \multirow[t]{7}{*}{ International activities } & First international sale: who, where and when \\
\hline & How decide \\
\hline & Number of countries \\
\hline & Entry timings \\
\hline & Percent of sales from international \\
\hline & How to get access \\
\hline & How welcome were approaches \\
\hline \multirow[t]{7}{*}{ Intra-network relations } & What gets shared (examples) \\
\hline & Topics discussed \\
\hline & How willing to share \\
\hline & How active \\
\hline & The frequency of meetings: formal and informal \\
\hline & Introductions? Referrals? Commendations? (examples) \\
\hline & Any opportunism? Lack of sharing? (examples) \\
\hline \multirow[t]{6}{*}{ Trade shows and festivals } & Where \\
\hline & When \\
\hline & Who organises \\
\hline & Who pays \\
\hline & What shared \\
\hline & Who meet \\
\hline \multirow[t]{4}{*}{ Role of industry association } & Events \\
\hline & Coordinator knowledge and contacts \\
\hline & Access information \\
\hline & Collective presence orchestration \\
\hline \multirow[t]{3}{*}{ Reputation } & Awards \\
\hline & Happy for others? \\
\hline & Payoff? Benefits? \\
\hline
\end{tabular}

Table AI.

Interview schedule topics and prompts
Education/training

International work experience

Firm(s)

Country(ies)

How decide

Number of countries

Entry timings

Percent of sales from international

How to get acces

Topics discussed

How willing to share

How active

The frequency of meetings: formal and informal

Any opportunism? Lack of sharing? (examples)

Where

When

Events

Coordinator knowledge and contacts

Awards

Payoff? Benefits?

\section{Corresponding author}

Natasha Evers can be contacted at: natasha.evers@nuigalway.ie

For instructions on how to order reprints of this article, please visit our website: 